\title{
Weldability of Aluminum Alloy and Hot Dip Galvanized Steel by AC Pulse MIG Brazing
}

\author{
Yong-Hyuk Kwon*, Sol-Choi**, $\$$, Hye-Seul Yoon***, and Hee-Seon Bang**** \\ *Dept. of Mechanical Engineering, Chosun College of Science \& Technology, Gwangju, 61453, Korea \\ **Korea Automotive Technology Institute, Gwangju, 62465, Korea \\ ***Graduate School, Dept. of Welding and Joining Science Engineering, Chosun Univ., Gwangju, 61452, Korea \\ ****Dept. of Welding and Joining Science Engineering, Chosun Univ., Gwangju, 61452, Korea \\ †Corresponding author: schoi@katech.re.kr \\ (Received October 15, 2020; Revised November 30, 2020; Accepted March 12, 2021)
}

\begin{abstract}
This study investigates the weldability of dissimilar materials, such as A16061-T6 aluminum alloy and hot dip galvanized (GI) steel, via AC pulse metal inert gas (MIG) brazing. Notably, the brazing mechanism was investigated for different electrode negative (EN) ratios. The results showed that as the amount of deposition increased with the EN ratio, throat thickness, wetting length, and leg length also tended to increase. Furthermore, it was confirmed that as the EN ratio increased, a thin intermetallic compound (IMC) layer was deposited due to the suppression of IMC growth caused by the low heat input at the joint interface.
\end{abstract}

Key Words: AC pulse MIG brazing, Dissimilar materials, EN ratio, Intermetallic compound layer

\section{Introduction}

In the face of grave crises such as global warming and resource depletion, CAFE (Corporate Average Fuel Economy) standards are being enforced upon the automotive industry worldwide. In fact, among all global industrial sectors, GHG (Green House Gases) emissions from transportation alone amount up to $25 \%{ }^{1)}$.

For this, the use of non-ferrous metals such aluminum alloy or magnesium alloy as material for automotive body has gradually multiplied over the years. Therefore, it is imperative to acquire the technology for the joining of dissimilar materials between steel and non-ferrous metal $^{2,3)}$.

The dissimilar materials used in the weight reduction of the automotive body are mainly aluminum alloy and steel. As in the case of dissimilar material joints, it is extremely difficult to secure appropriate strength and durability due to the intermetallic compounds layer that form at the bonding interface during fusion welding ${ }^{4)}$.

In particular, research on using aluminum alloy as lightweight material is actively conducted. Aluminum alloy has a specific gravity of only one third of that of steel, and are advantageous in both formability and corrosion resistance ${ }^{5}$. The application of hot-dip galvanized steel with improved corrosion resistance, to the making of the automotive body is growing as well ${ }^{6}$.

To discover the most effective way to join steel and aluminum alloy, many researchers have studied various methods including explosion welding, ultrasonic welding, friction stir welding, laser welding, laser-hybrid welding, and arc brazing ${ }^{7}$. However, application of these methods is problematic in that low productivity and expensive equipment ${ }^{8}$.

Recently the arc brazing process has been adopted as the technology of joining aluminum alloys and stainless steel. AC pulse MIG brazing is arc welding, based on alternating between direct current electrode positive (DCEP) and direct current electrode negative (DCEN) repeating pulsed waveforms, and it reduce spatter and high quality of weldability. Therefore, this method that can significantly improve the quality of the joints with periodic transfer ${ }^{9-13)}$. Furthermore, the amount of heat input in base material is less because it uses pulsed current instead of direct current (DC). Subsequently, using 
AC pulse can be obtained with large bonding area in spite of less heat input.

This study has tried to apply AC pulse MIG brazing to join dissimilar materials Al6061-T6 aluminum alloy and GI steel. In particular, the effect of EN ratio on the brazing mechanism and weldability in joints has been investigated and evaluated.

\section{Experimental Procedure}

In the present study, $2 \mathrm{~mm}$ thick Al6061-T6 aluminum alloy sheets and $2 \mathrm{~mm}$ thick GI steel sheets, whose dimensions were $200 \mathrm{~mm}(\mathrm{~L}) \times 100 \mathrm{~mm}(\mathrm{~B})$ were welded by AC pulse MIG brazing. As shown in Fig. 1, with an overlap joint of $20 \mathrm{~mm}$, the lap joint of $2 \mathrm{~mm}$ thick dissimilar materials was conducted without any gaps in between. 4047 aluminum alloy wire with a diameter of $1.2 \mathrm{~mm}$ was used as filler material, and the CTWD (Contact tip to work distance) was fixed at 15 $\mathrm{mm}$. In addition, the shielding gas used was $100 \% \mathrm{Ar}$ gas with a flow rate of $181 / \mathrm{min}$. In order to investigate the effect of EN ratio on weldability of joints, the EN ratio was varied at $0 \%, 10 \%$, and $20 \%$ for welding current of $50 \mathrm{~A}, 60 \mathrm{~A}$, and $70 \mathrm{~A}$.

The welding process parameters are shown in Table 1. The chemical compositions and mechanical properties of Al6061-T6 aluminum alloy, GI steel and 4047 aluminum alloy filler wire used in the experiment are shown in Table 2, 3, and 4, respectively.

The AC pulse MIG welding machine and 6-axis robot used in this study are the DW-300 and FD-V6,

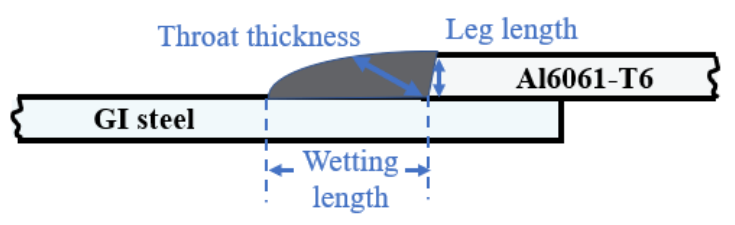

Fig. 1 Schematic of Al6061-T6 aluminum alloy and GI steel lap joints
Table 1 Welding parameters

\begin{tabular}{|l|c|}
\hline Welding process & $\begin{array}{c}\text { AC pulse MIG } \\
\text { brazing }\end{array}$ \\
\hline Type of joint & Lap joint \\
\hline Overlapping length $(\mathrm{mm})$ & 20 \\
\hline Electrode type & ER 4047 \\
\hline Electrode diameter (mm) & 1.2 \\
\hline Travel speed (cm/min) & 50 \\
\hline Work angle/Drag angle (degree) & $10 / 10$ \\
\hline Gap (mm) & $0 \mathrm{~mm}$ \\
\hline Shielding gas $(\%)$ & $\mathrm{Ar} 100 \%$ \\
\hline Shielding gas flow rate $(1 / \mathrm{min})$ & 18 \\
\hline Contact tip to work distance $(\mathrm{mm})$ & 15 \\
\hline EN ratio (\%) & $0,10,20$ \\
\hline Current (A) & $50,60,70$ \\
\hline
\end{tabular}

manufactured by Japanese company OTC Daihen as shown in Fig. 2.

\section{Results and Discussions}

\subsection{Bead profiles}

Fig. 3 shows the bead formation with the EN ratio for the joining of Al6061-T6 aluminum alloy and GI steel. All experiments were conducted under the conditions at EN ratio of $0 \%, 10 \%$, and $20 \%$ for welding currents of $50 \mathrm{~A}, 60 \mathrm{~A}$, and $70 \mathrm{~A}$.

The throat thickness, leg length, and wetting length of joints are shown in Table 4.

As shown in Fig. 3, with increases in the EN ratio, the melting rate and deposition rate of filler material increase, and less $\mathrm{Zn}$ damage to the joint reduces the occurrence of porosity in the root area and inside of joints ${ }^{19,20)}$. It was observed that as the EN ratio increased, throat thickness, leg length, and wetting length tended to increase slightly regardless of different currents. In order to achieve good weld strength, an effective leg

Table 2 Chemical composition of Al6061-T6 aluminum alloy ${ }^{15)}$, GI steel ${ }^{17)}$ and 4047 aluminum alloy wire ${ }^{16)}$ [Unit: wt \%]

\begin{tabular}{|c|c|c|c|c|c|c|c|c|}
\hline \multirow{2}{*}{$\mathrm{Al} 6061-\mathrm{T} 6$} & $\mathrm{Si}$ & $\mathrm{Fe}$ & $\mathrm{Cu}$ & $\mathrm{Mn}$ & $\mathrm{Mg}$ & $\mathrm{Cr}$ & $\mathrm{Zn}$ & $\mathrm{Al}$ \\
\cline { 2 - 8 } & $0.4 \sim 0.8$ & 0.7 & $0.15 \sim 0.4$ & 0.15 & 0.1 & $0.04 \sim 0.35$ & 0.25 & $\mathrm{Bal}$. \\
\hline \multirow{2}{*}{ GI steel } & $\mathrm{C}$ & $\mathrm{Si}$ & $\mathrm{Mn}$ & $\mathrm{P}$ & $\mathrm{S}$ & $\mathrm{Sol}-\mathrm{Al}$ & $\mathrm{Fe}$ \\
\cline { 2 - 9 } & 0.012 & 0.01 & 0.15 & 0.015 & 0.007 & 0.032 & $\mathrm{Be}$ & $\mathrm{Zn}$ \\
\hline \multirow{2}{*}{$\begin{array}{c}4047 \text { aluminum } \\
\text { alloy wire }\end{array}$} & $\mathrm{Si}$ & $\mathrm{Fe}$ & $\mathrm{Cu}$ & $\mathrm{Mn}$ & $\mathrm{Mg}$ & $\mathrm{Bl}$ \\
\cline { 2 - 9 }
\end{tabular}


Table 3 Mechanical properties of Al6061-T6 aluminum al$\operatorname{loy}^{15)}$, GI steel ${ }^{17)}$ and 4047 aluminum alloy wire ${ }^{16)}$

\begin{tabular}{|c|c|c|c|}
\hline Material & $\begin{array}{c}\text { Yield strength } \\
\text { (MPa) }\end{array}$ & $\begin{array}{c}\text { Tensile strength } \\
\text { (MPa) }\end{array}$ & $\begin{array}{c}\text { Elongation } \\
(\%)\end{array}$ \\
\hline Al 6061-T6 & 276 & 310 & 12 \\
\hline GI Steel & 164 & 294 & 53 \\
\hline $\begin{array}{c}4047 \text { aluminum } \\
\text { alloy wire }\end{array}$ & 131 & 268 & 17 \\
\hline
\end{tabular}

Table 4 The throat thickness, leg length, and wetting length of joints with EN ratio [Unit: $\mathrm{mm}$ ]

\begin{tabular}{|c|c|c|c|c|}
\hline Current & $\begin{array}{c}\text { EN ratio } \\
(\%)\end{array}$ & $\begin{array}{c}\text { Throat } \\
\text { thickness }\end{array}$ & $\begin{array}{c}\text { Wetting } \\
\text { length }\end{array}$ & $\begin{array}{c}\text { Leg } \\
\text { length }\end{array}$ \\
\hline \multirow{3}{*}{$50 \mathrm{~A}$} & 0 & 4.78 & 7.60 & 2.70 \\
\cline { 2 - 5 } & 10 & 5.32 & 7.80 & 2.80 \\
\cline { 2 - 5 } & 20 & 5.6 & 7.80 & 2.90 \\
\hline \multirow{3}{*}{$60 \mathrm{~A}$} & 0 & 5.56 & 9.22 & 2.0 \\
\cline { 2 - 5 } & 10 & 6.26 & 9.48 & 2.18 \\
\cline { 2 - 5 } & 20 & 6.85 & 9.99 & 2.2 \\
\hline \multirow{3}{*}{$70 \mathrm{~A}$} & 0 & 6.13 & 11.0 & 1.9 \\
\cline { 2 - 5 } & 10 & 6.68 & 11.34 & 1.95 \\
\cline { 2 - 5 } & 20 & 7.10 & 11.48 & 2.5 \\
\hline
\end{tabular}

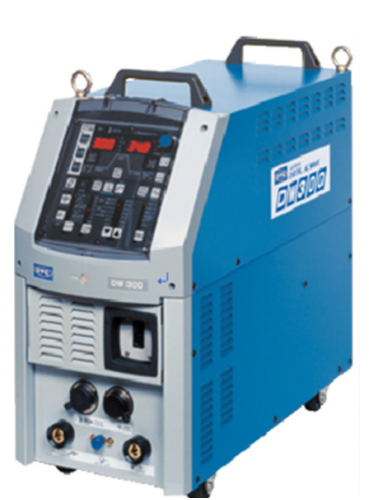

(a) AC pulse MIG welding machine

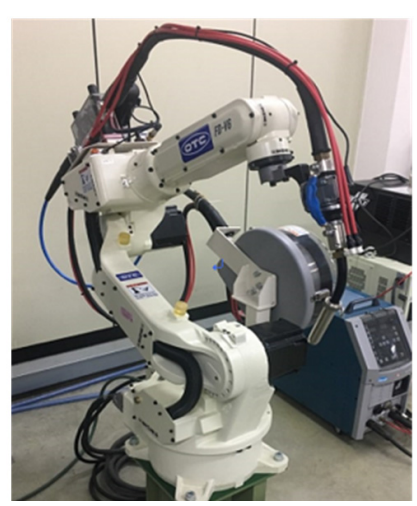

(b) 6-axis robot
Fig. 2 AC pulse MIG welding machine and 6-axis welding robot length with more than $2 \mathrm{~mm}$ of objective sheet thickness must be generated. At the welding current of $50 \mathrm{~A}$ and $60 \mathrm{~A}$, the actual leg length over $2 \mathrm{~mm}$ could be obtained. It was also possible to obtain a longer wetting length and throat thickness under $60 \mathrm{~A}$ than 50A. This means that welding current of $60 \mathrm{~A}$ produces more sound joints, compared with that of 50A and 70A.

\subsection{Tensile-shear load}

The results of the tensile-shear load tests are shown in Fig. 4 and Table 5. As the EN ratio increased, the tensile-shear load increased regardless of welding currents. This is attributed to longer throat thickness, leg length, wetting length and thinner intermetallic compounds layer formation, caused by high deposition rate and low heat input to the base metal.

The maximum tensile-shear load was acquired at 8.0 $\mathrm{kN}$ when the welding current was $70 \mathrm{~A}$ and $\mathrm{EN}$ ratio was $20 \%$. However, in the cross-sectional analysis, porosity

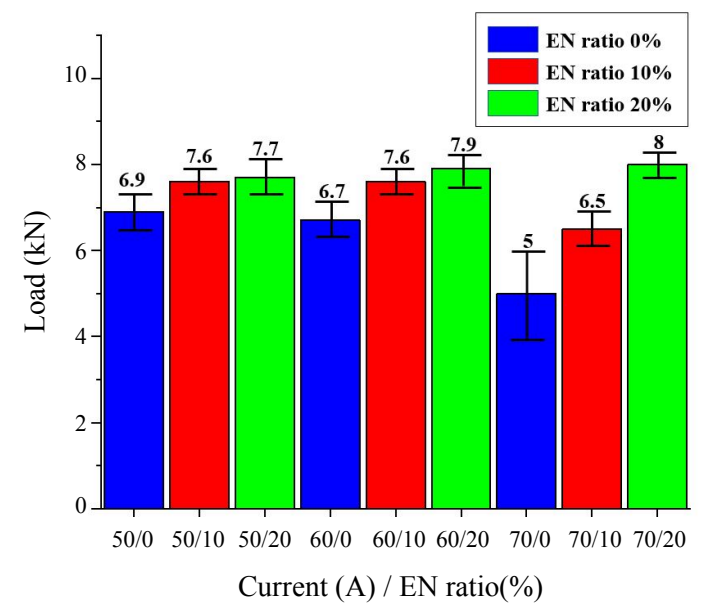

Fig. 4 Tensile-shear load with EN ratio for various welding currents

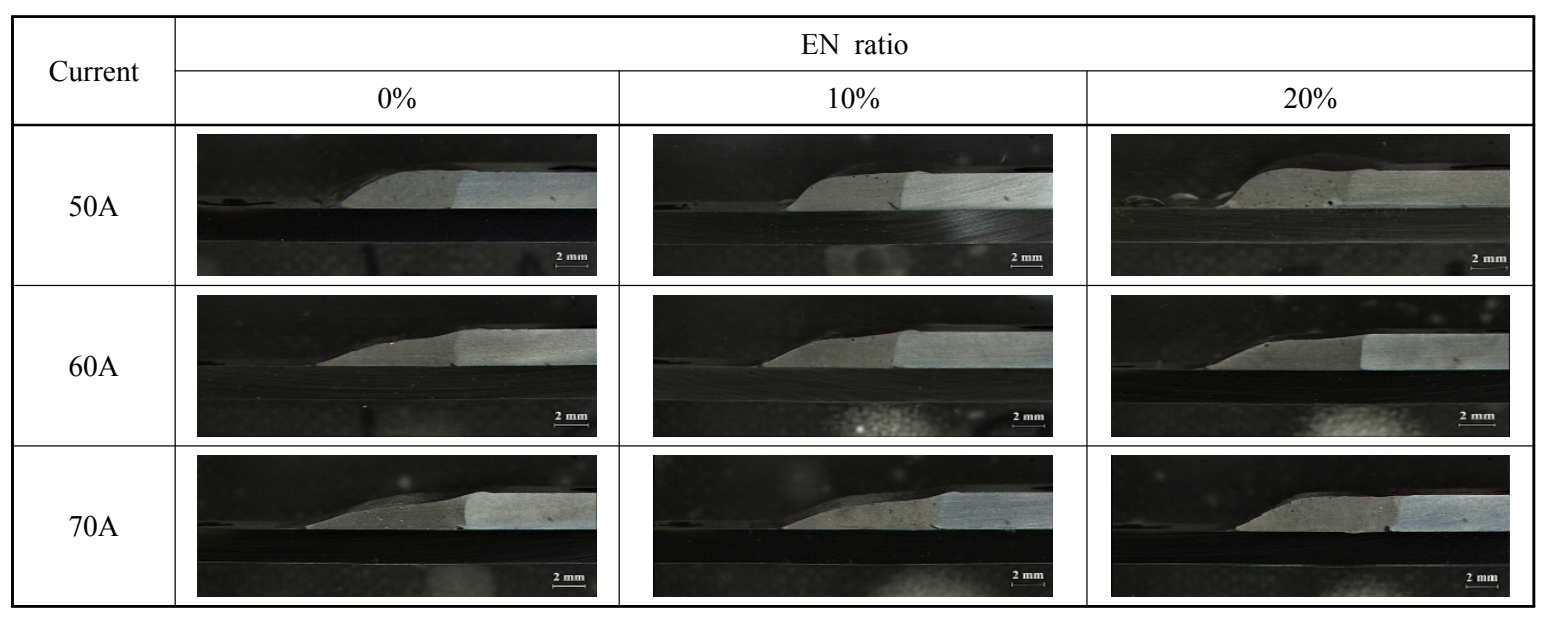

Fig. 3 Bead profiles with EN ratio 
Table 5 Results of tensile-shear load test

\begin{tabular}{|c|c|c|c|c|c|c|c|c|c|}
\hline Current & \multicolumn{3}{|c|}{50 A } & \multicolumn{3}{c|}{60 A } & \multicolumn{3}{c|}{70 A } \\
\hline EN Ratio (\%) & 0 & 10 & 20 & 0 & 10 & 20 & 0 & 10 & 20 \\
\hline Tensile-Shear load (kN) & 6.9 & 7.6 & 7.7 & 6.7 & 7.6 & 7.9 & 5 & 6.5 & 8.0 \\
\hline
\end{tabular}

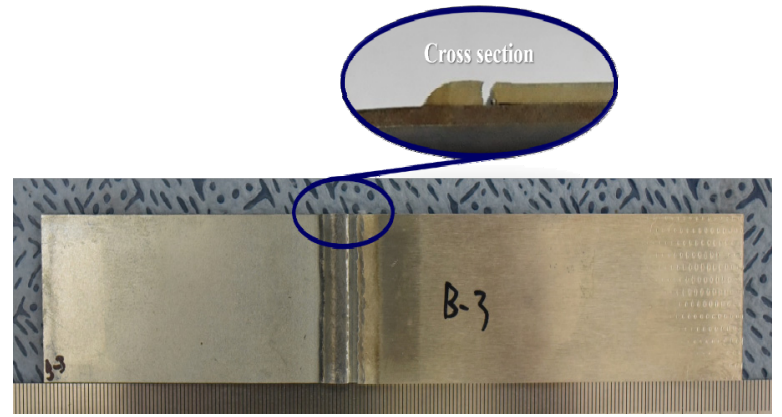

Fig. 5 Fractured specimen of tensile-shear load test

occurred at the root area even under the same conditions, which can cause of fatal defects in the stress concentration area. Under the condition of a welding current of $60 \mathrm{~A}$ and $\mathrm{EN}$ ratio of $20 \%$, porosity was not found at the root area, and the maximum tensile-shear load was acquired at $7.9 \mathrm{kN}$.

As a result, with an increase in the EN ratio, the tensile-shear load also gradually increased at all welding currents 50A, 60A, 70A, and the highest tensile-shear load was found at $20 \% \mathrm{EN}$ ratio.

In all tensile-shear load tests, local plastic deformation occurred intensively at the root and the toes are, as shown in Fig. 5. The fracture occurred in heat affected zone of Al6061-T6 aluminum alloy side, which heat affected zone of heat treated aluminum alloy is weakest area due to precipitation process.

\subsection{SEM-EDS analysis}

At the welding current of $50 \mathrm{~A}$ and $70 \mathrm{~A}$, an effective leg length with more than $2 \mathrm{~mm}$, longer wetting length and throat thickness could not be obtained, compared with those of $60 \mathrm{~A}$. Thus, this study intended to investigate the effect of EN ratio on intermetallic compound layer formation in joints at the welding current of 60A.

SEM analysis was carried out to examine the weldability of Al6061-T6 aluminum alloy and GI steel by AC pulse MIG brazing under the conditions of $0 \%$, $10 \%, 20 \%$ EN ratio in 60 welding current.

Fig. 6 shows the SEM images of joint interface at EN ratio of $0 \%, 10 \%, 20 \%$ in welding current of $60 \mathrm{~A}$. Under the condition of $\mathrm{EN}$ ratio of $0 \%$, the average thickness of the IMCs was $4.96 \mu \mathrm{m}$. Under EN ratio of $10 \%$, the thickness was $4.69 \mu \mathrm{m}$, and for EN ratio of $20 \%, 2.41 \mu \mathrm{m}$, respectively. From the results, it can be confirmed that the growth of the IMCs was suppressed as the EN ratio increased. This is because although the melting amount of the filler material increases as the EN ratio increases, the lower heat input leads to the decrease in the IMC layer formation at the joint interface between the filler material and GI steel.

For an analysis of the composition of the IMC formed at the EN ratio of $20 \%$ in welding current of $60 \mathrm{~A}$, EDS

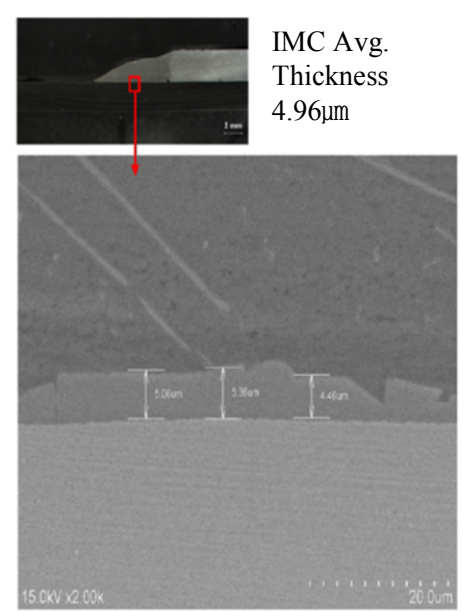

(a) EN ratio $0 \%$

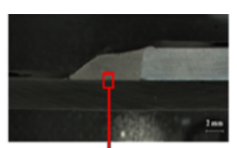

IMC Avg. Thickness $4.69 \mu \mathrm{m}$

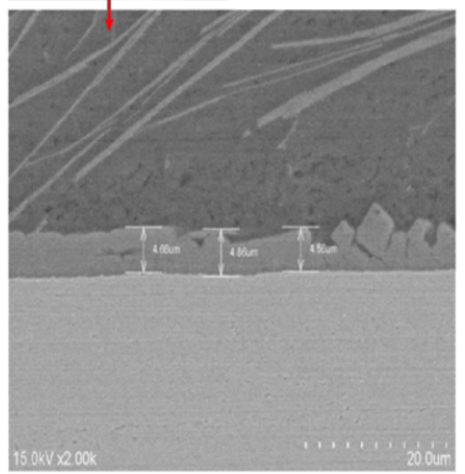

(b) EN ratio $10 \%$

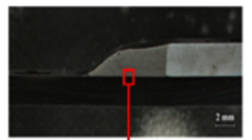

IMC Avg.

Thickness $2.41 \mu \mathrm{m}$

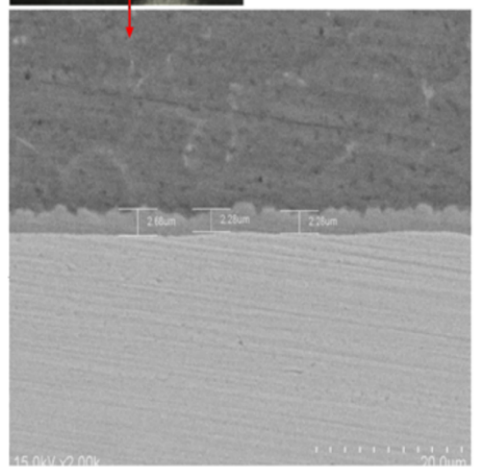

(c) EN ratio $20 \%$

Fig. 6 SEM images of joint interface at EN ratio of 0\%, 10\%, 20\%(2000 magnification ratio) 


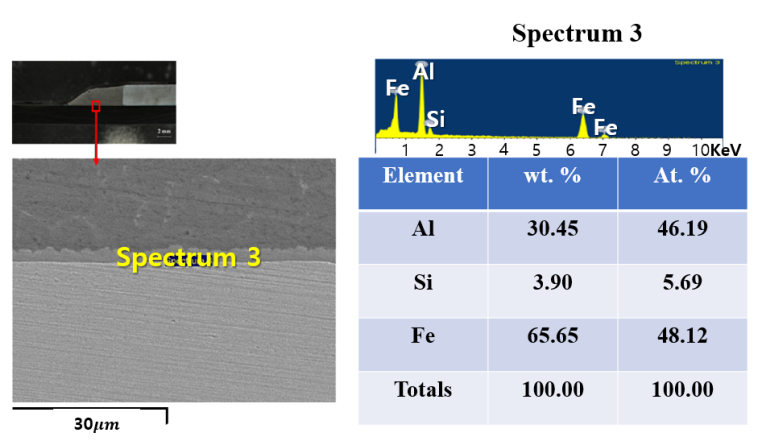

Fig. 7 EDS analysis on intermetallic compounds layer

analysis was performed. Fig. 7 shows the results of the EDS analysis on intermetallic compounds layer. The EDS analysis shows the constituent of $\mathrm{Al}, \mathrm{Fe}, \mathrm{Zn}$, and $\mathrm{Si}$. In addition, the amount of $\mathrm{Fe}$ in the area presumed to be IMCs gradually decreased from the GI steel interface toward the aluminum material. In contrast, aluminum gradually increased. $\mathrm{Zn}$, the plating layer of GI steel, has a melting point of about $420^{\circ} \mathrm{C}$ and a boiling point of about $907^{\circ} \mathrm{C}$, and thus evaporated due to the temperature gradient of the arc during brazing. As a result, the content distribution in the entire section was low, and it is understood that the content distribution slightly increased as it went from the center of the arc with the highest temperature toward the GI steel material. In the case of $\mathrm{Si}, 4047$ aluminum alloy wire was welded to the aluminum base material and the GI steel base material when the filler material was melted. It is presumed that some Si diffused into the joint interface layer to form an Al-Fe-Si ternary phase. The sight of Al being mixed with Fe can be seen, and from this, the formation of the IMC layer can be concluded.

For EDS analysis, a spot assumed to be the IMC layer was designated. According to the result of the analysis, $\mathrm{Fe}, \mathrm{Al}$, and $\mathrm{Si}$ were detected. It is believed that the during the initial brazing, growth of the Fe-Al based IMC was inhibited because of the melting and vaporization of $\mathrm{Zn}$, the plating layer of the GI steel interface, and the diffusion of Si constituent of the filler material into the Gl steel interface.

\section{Conclusion}

In this study, weldability according to $\mathrm{EN}$ ratio were evaluated in the AC pulse MIG brazing of Al6061-T6 and GI steel. For this, the mechanical properties and brazing mechanism according to the EN ratio were investigated.

1) When EN ratio was $20 \%$, high tensile-shear loads were obtained under all conditions of welding currents, $50 \mathrm{~A}, 60 \mathrm{~A}$, and $70 \mathrm{~A}$. With the increase of $\mathrm{EN}$ ratio, the melting rate and deposition rate of filler material also rose, along with the tendency of throat thickness, wetting length, and leg length to increase. An effective leg length with more than $2 \mathrm{~mm}$, longer wetting length and throat thickness can be achieved under the welding current of $60 \mathrm{~A}$, and generation of porosity reduces in the root area and inside of joints in EN ratio of $20 \%$.

2) From the SEM analysis, it could be confirmed that as the EN ratio increased, thinner intermetallic compound layer was achieved due to the suppression of growth of the intermetallic compounds layer caused by lower heat input to the joint interface.

3) According to the EDS analysis, Fe-Al-Si was detected in the intermetallic compound generated at the bonding interface between Al6061-T6 and GI steel. It can be deduced that the ternary Fe-Al-Si mixed layer was formed due to the following factors: the melting and vaporization of $\mathrm{Zn}$, the plating layer of GI steel, during the first brazing and the diffusion of the Si constituent of the filler material onto the joint interface.

4) Thus, in terms of mechanical and microstructural characteristics, it could be concluded that the optimum welding condition was a welding current of $60 \mathrm{~A}$ with EN ratio of $20 \%$, showing the maximum tensile-shear load of $7.9 \mathrm{kN}$ and thinnest thickness of intermetallic compounds layer of $2.41 \mu \mathrm{m}$.

ORCID: Yong-Hyuk Kwon: https://orcid.org/0000-0002-7600-5575 ORCID: Sol-Choi: https://orcid.org/0000-0002-6712-4353

ORCID: Hye-Seul Yoon: https://orcid.org/0000-0001-9992-6791

ORCID: Hee-Seon Bang: https://orcid.org/0000-0003-4891-5712

\section{References}

1. M. Meinshausen, N. Meinshausen, W. Hare, S. C. B Raper, K. Frieler, R. Knutti, and M. R. Allen, Greenhouse -gas emission targets for limiting global warming to $2{ }^{\circ} \mathrm{C}$, Nat. 458(7242) (2009) 1158-1162.

https://doi.org/10.1038/nature08017

2. M. Tisza and I. Czinege, Comparative study of the application of steels and aluminium in lightweight production of automotive parts, Int. J. Lightweight Mater. Manuf. 1(4) (2018) 229-238.

https://doi.org/10.1016/j.ijlmm.2018.09.001

3. D. J. Hemanth, V. D. Ambeth Kumar, S. Malathi, O. Castillo, and B. Patrut, Emerging Trends in Computing and Expert Technology, 1st. ed., springer, Cham, Switzerland (2020) 519-531. https://doi.org/10.1007/978-3-030-32150-5_50

4. M. Abdul Karim, Y. D. Park, A Review on Welding of Dissimilar Metals in Car Body Manufacturing, J. Weld. Join. 38(1) (2020) 8-23. https://doi.org/10.5781/JWJ.2020.38.1.1

5. J. R. Davis, Alloying, Understanding the Basics, Alloying: Understanding the Basics, 1st edition, ASM International, Ohio, USA (2001) 351-416. 
6. N. K Akafuah, S. Poozesh, A. Salaimeh, G. Patrick, K. Lawler, and K. Saito, Evolution of the Automotive Body Coating Process-A Review, Coat. 6(2) (2016) 24. https://doi.org/10.3390/coatings6020024

7. Y. Kim and B. Y. Lee, A Study on the Dissimilar Metal Joining of Aluminum to Steel Using the Arc Heat Source (I ) - Research Trends and Comparison of the Processes, J. Weld. Join. 36(4) (2018) 1-12. https://doi.org/10.5781/JWJ.2018.36.4.1

8. P. Kah, M. Shrestha, J. Martikainen, Trends in Joining Dissimilar Metals by Welding, Appl. Mech. Mater. 440 (2013) 269-276

https://doi.org/10.4028/www.scientific.net/amm.440.269

9. S. Liu, A. Suzumura, T. T. Taka, and T. Yamazaki, Brazing of Stainless Steel to Various Aluminum Alloys in Air, JSME Int. J. Ser. A, 48(4) (2005) 420-425. https://doi.org/10.1299/jsmea.48.420

10. M. Cheepu, B. Srinivas, N. Abhishek, T. Ramachandraiah, S. Karna, D. Venkateswarlu, and W. S. Che, Dissimilar Joining of Stainless Steel and 5083 Aluminum Alloy Sheets by Gas Tungsten Arc Welding-Brazing Process, IOP Conf. Ser: Mater. Sci. (IOP 2018), Hydrabed, India (2018) 012048. https://doi.org/10.1088/1757-899x/330/1/012048

11. H. Zhang and J. Liu, Microstructure characteristics and mechanical property of aluminum alloy/stainless steel lap joints fabricated by MIG welding-brazing process, Mater. Sci. Eng. A, 528(19-20) (2011) 6179-6185. https://doi.org/10.1016/j.msea.2011.04.039

12. H. J. Park, S. Rhee, M. J. Kang, and D. C. Kim, Joining of Steel to Aluminum Alloy by AC Pulse MIG Welding, Mater. Trans. 50(9) (2009) 2314-2317. https://doi.org/10.2320/matertrans.M2009105

13. J. Li, H. Li, H. Wei, and Y. Ni, Effect of pulse on pulse frequency on welding process and welding quality of pulse on pulse MIG welding-brazing of aluminum alloys to stainless steel, Int. J Adv. Manuf. Technol. 87 (2016) 51-63.

https://doi.org/10.1007/s00170-016-8369-y
14. S. W. Kang and B. S. Jang, Friction Stir Welding Analysis Based on Equivalent Strain Method using Neural Networks, Int. J. Ocean. Syst. Eng. 28(5) (2014) 452-465. https://doi.org/10.5574/KSOE.2014.28.5.452

15. H. S. Bang, H. S. Bang, G. H. Jeon, I. H. Oh, and C. S. Ro, Gas tungsten arc welding assisted hybrid friction stir welding of dissimilar materials Al6061-T6 aluminum alloy and STS304 stainless steel, Mater. Des. 37 (2012) 48-55. https://doi.org/10.1016/j.matdes.2011.12.018

16. J. L. Song, S. B. Lin, C. L. Yang, G. C. Ma, and H. Liu, Spreading behavior and microstructure characteristics of dissimilar metals TIG welding-brazing of aluminum alloy to stainless steel, Mater. Sci. Eng. A, 509 (2009) 31-40. https://doi.org/10.1016/j.msea.2009.02.036

17. P. A. Dhawale and B. P. Ronge, Parametric optimization of resistance spot welding for multi spot welded lap shear specimen to predict weld strength, Mater. Today, 19(2) (2019) 700-707. https://doi.org/10.1016/j.matpr.2019.07.756

18. S. LIN, J. Song, G. MA, and Ch. YANG, Dissimilar metals TIG welding-brazing of aluminum alloy to galvanized steel, Front. Mater. Sci. China, 3(1) (2009) 78-83. https://doi.org/10.1007/s11706-009-0007-2

19. M. J. Kang, Y. J. Ahn, and C. H. Kim, Porosity Reduction during Gas Tungsten Arc-Gas Metal Arc Hybrid Welding of Zinc Coated Steel Sheets (I) - Effect of Preceding GasTungsten Arc, J. Weld. Join. 34(4) (2016) 40-47. https://doi.org/10.5781/JWJ.2016.34.4.40

20. S. M. Cho, K. J. Kim, and B. W. Lee, The Waveform Control and Blowhole Generation in the Wave Pulse MIG Welding for Galvanized Steel Sheets, J. Korean Weld. Join. Soc. 23(1) (2005) 69-76. 